\title{
EKSPERIMENTASI MODEL PROBLEM BASED LEARNING (PBL) DAN MODEL PEMBELAJARAN MISSOURI MATHEMATICS PROJECT (MMP) DITINJAU DARI SIKAP SISWA TERHADAP MATEMATIKA PADA MATERI PERSAMAAN DAN PERTIDAKSAMAAN LINEAR SATU VARIABEL KELAS VII SMP NEGERI SE-KABUPATEN BELITUNG TAHUN PELAJARAN 2014/2015
}

\author{
Firna Irnistisia ${ }^{1}$, Tri Atmojo Kusmayadi ${ }^{2}$ Riyadi $^{3}$ \\ ${ }^{1,2,3}$ Prodi Magister Pendidikan Matematika, FKIP Universitas Sebelas Maret, Surakarta
}

\begin{abstract}
The objective of this research was to investigate the effect of the learning models on the learning achievement in mathematics viewed from students attitude toward mathematics. The learning models compared were the problem based learning (PBL) type, the cooperative learning model of the missouri mathematics project (MMP) type, and the direct learning model. This research used the quasi experimental research. Its population was all of the students in Grade VII of State Junior Secondary Schools of Belitung regency in Academic Year 2014/2015. The samples of the research were taken by using the stratified cluster random sampling technique and consisted of 285 students. They were grouped into three classes, namely: 95 students in Experimental Class 1, 96 students in Experimental Class 2, and 94 students in Control Class. The instruments to gather the data were test of achievement in learning mathematics and the students attitude toward mathematics questionnaire. The proposed hypotheses of the research were analyzed by using the two way analysis of variance with unbalanced cells. The results of the research were as follows. 1) The cooperative learning model of the PBL type results in a better learning achievement in Mathematics than the cooperative learning model of the MMP type and the direct learning model, the cooperative learning model of the MMP type results in a better learning achievement in Mathematics than the direct learning model. 2) The students with the high attitudes toward mathematics have a better learning achievement in mathematics than those with the moderate students attitudes toward mathematics and those with the low students attitudes toward mathematics, the students with the moderate attitudes toward mathematics have a better learning achievement in mathematics than those with the low students attitudes toward mathematics. 3) There was an interaction the aforementioned learning models and the categories students attitude toward mathematics on the learning achievement in mathematics of the students.
\end{abstract}

Keywords: PBL, MMP, and students attitude toward mathematics.

\section{PENDAHULUAN}

Pendidikan di sekolah menuntut siswa dapat menguasai konsep materi pelajaran.

Salah satu konsep yang diperlukan dalam kehidupan sehari-hari adalah konsep pada mata pelajaran matematika. Matematika sebagai salah satu mata pelajaran di sekolah tidak hanya digunakan untuk melatih kecerdasan berpikir saja serta dapat memiliki sikap dan kebiasaan berpikir logis, kritis, sistematik, kerja cepat, tekun dan bertanggungjawab dalam memahami konsep-konsep dan struktur-struktur matematika.

Penguasaan materi matematika dapat diukur dari tes prestasi belajar. Akan tetapi prestasi dalam matematika masih jauh dari yang diharapkan. Indikator rendahnya prestasi 
belajar matematika diperkuat dengan data nilai ujian nasional (UN) tiga tahun terakhir untuk tingkat SMP Negeri di Kabupaten Belitung dapat dilihat pada Tabel 1.

Tabel 1 Nilai Rata-rata Ujian Nasional Matematika

\begin{tabular}{cccc}
\hline Tahun Pelajaran & Kab.Belitung & Provinsi & Nasional \\
\hline $2011 / 2012$ & 5,78 & 6,30 & 7,64 \\
$2012 / 2013$ & 5,66 & 5,85 & 6,70 \\
$2013 / 2014$ & 4,26 & 4,51 & 6,10 \\
\hline
\end{tabular}

Adapun pemilihan materi persamaan dan pertidaksamaan linear satu variabel berdasarkan persentase daya serap ujian nasional (UN) materi persamaan dan pertidaksamaan linear satu variabel. Persentase daya serap siswa berdasarkan UN dari tahun pelajaran 2011/2012 sampai pada tahun 2013/2014.

Daya serap UN materi persamaan dan pertidaksamaan linear satu variabel di Kabupaten Belitung dari tahun pelajaran 2011/2012 sampai pada tahun 2013/ 2014 mengalami naik turun. Pada persoalan menyelesaikan masalah yang berkaitan dengan persamaan dan pertidaksamaan linear satu variabel di tahun 2011/2012 daya serap nya $35,28 \%$. Kemudian di tahun 2012/2013 daya serapnya 39,00\% dan pada tahun 2013/2014 daya serapnya $31,07 \%$.

Naik turunnya persentase daya serap pada 3 tahun terakhir menandakan pemahaman pada materi tersebut masih kurang. Kesalahan tersebut terjadi saat proses belajarnya dikarenakan guru kurang memahami konsep yang akan disampaikan sehingga guru salah menjelaskan konsep tersebut kepada siswa. Perlu disadari bahwa setiap materi pada pelajaran matematika saling berkaitan sehingga kehilangan sebuah konsep dapat mengganggu proses pembelajaran berikutnya.

Prestasi belajar seorang siswa dalam proses pembelajaran ditentukan oleh faktor internal dan faktor eksternal. Salah satu faktor internal adalah sikap siswa pada matematika. Hal serupa disampaikan oleh Faroq and Shah (2008) bahwa

"Students success in mathematics depends upon attitude towards mathematics. Attitude towards mathematics plays a crucial role in the teaching and learning processes of mathematics."

Kesuksesan siswa dalam matematika bergantung pada sikap terhadap matematika. Sikap terhadap matematika memainkan peran yang penting dalam proses mengajar dan pembelajaran matematika. Menurut Mahanta (2012: 158) bahwa

"attitude towards mathematics denotes interest or feeling of involvement towards studying mathematics. Attitude towards mathematics means mathematical or scientific approach assumed by an individual for solving problems, readiness to respond by associating ideas and making decisions and assessments".

Sikap terhadap matematika menunjukkan minat atau perasaan keterlibatan terhadap belajar matematika. Sikap terhadap matematika berarti pendekatan ilmiah yang diasumsikan oleh seorang individu untuk pemecahan masalah, kesiapan untuk merespon 
dengan menghubungkan ide dan pengambilan keputusan dan penilaian. Belajar dengan minat akan mendorong siswa belajar lebih baik. Minat ini timbul apabila siswa tertarik atau senang sesuatu yang akan dipelajari karena akan bermakna bagi dirinya. Minat tanpa adanya usaha sikap yang baik, maka belajar akan sulit berhasil.

Guru memegang peranan penting dalam proses belajar mengajar. Awofala (2014: 284) menyatakan bahwa "Because mathematics teachers are among the most important factors in student learning of mathematics, they have the onerous task of implementing effective instructional strategy capable of positively influencing students' attitudes toward mathematics". Karena guru matematika adalah salah satu faktor paling penting dalam belajar siswa matematika, mereka memiliki tugas berat menerapkan strategi pembelajaran yang efektif mampu mempengaruhi sikap positif siswa terhadap matematika.

Salah satu pembelajaran yang membuat siswa lebih aktif adalah pembelajaran kooperatif. Pembelajaran kooperatif merupakan suatu model pembelajaran dimana siswa belajar dalam kelompok-kelompok kecil yang memiliki tingkat kemampuan yang berbeda. Dalam menyelesaikan tugas kelompok, setiap anggota saling bekerja sama dan membantu untuk memahami suatu bahan pembelajaran kerja kelompok merupakan bagian dan bukan hanya sekedar cara untuk mencapai tujuan. Hal yang sama juga dinyatakan oleh Kiran et al. (2012: 141) "cooperative learning is a teaching approach in which students work cooperatively in small teams with individuals of different talents, abilities and background to complete a common goal".

Zakaria dan lksan (2007) menyatakan bahwa "cooperative learning is grounded in the belief that learning is most effective when students are actively involved in sharing ideas and work cooperatively to complete academic tasks". Pembelajaran kooperatif didasarkan pada keyakinan bahwa belajar yang paling efektif adalah ketika siswa terlibat secara aktif dalam berbagi ide dan bekerja sama untuk menyelesaikan tugas akademik. Menurut Johnson dan Johnson (dalam Kupczynski, 2012) "The Cooperative Learning model incorporates five essential element: Positive interdependence, individual accountability, face to face promotive interaction, social skills, and group processing". Model pembelajaran kooperatif menyertakan lima elemen penting: saling ketergantungan, tanggung jawab individu, berinteraksi, kemampuan bersosial, dan proses kelompok. Salah satu tipe model pembelajaran kooperatif yang dapat mendorong partisipasi siswa lebih aktif dalam kelas adalah model pembelajaran MMP dan PBL.

Pelaksanaan PBL mempunyai tujuan utama seperti yang dikemukakan oleh Ball dan Pelco (2006: 148) bahwa 
"To encourage self-directed learning in the students that leads to higher motivation, better retention of material, and the development of important reasoning and problem-solving skills, and to develop a better understanding in students of the group processes and skills necessary for successful working collaborations".

PBL mendorong siswa agar mampu mengarahkan dirinya sendiri dalam belajar pada motivasi yang lebih tinggi, ingatan materi yang lebih baik, perkembangan dalam bernalar dan keterampilan menyelesaikan masalah, serta mengembangkan pemahaman yang lebih baik pada siswa dari proses kelompok dan kebutuhan keterampilan demi suksesnya kerjasama kerja.

Menurut Albesene dan Mitchell (1993) serta Vernon dan Blake (1993) dalam Bilgin et al. (2009: 155) menyatakan bahwa "PBL encourages students to become more involved in, and responsible for, their own learning, and most students and faculty report that this is highly enjoyable way to learn and teach". PBL mendorong siswa untuk menjadi lebih terlibat dan bertanggung jawab untuk belajar sendiri dan sebagian besar siswa menyatakan bahwa ini adalah cara yang sangat menyenangkan untuk belajar dan mengajar.

Sedangkan Pembelajaran model Missouri Mathematics Project (MMP) menuntut siswa untuk bisa menyajikan masalah dan mencari strategi dalam rangka memecahkan permasalahan matematika yang mereka hadapi baik secara kelompok maupun individual. Keunggulan lain dari model MMP adalah materi yang diterima siswa relatif banyak karena alokasi waktu yang diperlukan tidak memerlukan waktu yang banyak dan siswa terampil karena banyak latihan yang dikerjakan.

Berdasarkan latar belakang masalah di atas maka, penelitian ini bertujuan untuk: (1) Mengetahui model pembelajaran mana yang menghasilkan prestasi belajar antara model PBL, model pembelajaran MMP atau model pembelajaran langsung. (2) Mengetahui kategori sikap siswa mana yang mempunyai prestasi belajar matematika yang lebih baik antara siswa dengan sikap tinggi, sedang atau rendah terhadap matematika. (3) Mengetahui pada masing-masing model pembelajaran, kategori sikap mana yang menghasilkan prestasi belajar yang lebih baik siswa dengan sikap tinggi, sedang dan rendah tehadap matematika. (4) Mengetahui pada masing-masing kategori sikap siswa mana yang menghasilkan prestasi belajar yang lebih baik, antara siswa yang diberikan model PBL, model pembelajaran MMP atau model pembelajaran langsung.

\section{METODE PENELITIAN}

Penelitian dilaksanakan pada semester genap tahun pelajaran 2014/2015 dengan jenis penelitian quasi-experimental, desain faktorial penelitian disajikan dalam Tabel 2. 
Tabel 2. Desain Faktorial Penelitian

\begin{tabular}{lllll}
\hline & Variabel bebas 2 & \multicolumn{3}{c}{ Sikap siswa terhadap matematika $(b)$} \\
\cline { 2 - 5 } Variabel bebas 1 & & $\begin{array}{c}\text { Tinggi } \\
\left(b_{1}\right)\end{array}$ & $\begin{array}{c}\text { Sedang } \\
\left(b_{2}\right)\end{array}$ & $\begin{array}{c}\text { Rendah } \\
\left(b_{3}\right)\end{array}$ \\
\hline \begin{tabular}{l} 
Model $\begin{array}{l}\text { Pembelajaran } \\
(a)\end{array}$ \\
\cline { 2 - 5 }
\end{tabular} & & $(a b)_{11}$ & $(a b)_{12}$ & $(a b)_{13}$ \\
\cline { 2 - 6 } & $\operatorname{PBL}\left(a_{1}\right)$ & $(a b)_{21}$ & $(a b)_{22}$ & $(a b)_{23}$ \\
\cline { 2 - 6 } & Pembelajaran langsung $\left(a_{3}\right)$ & $(a b)_{31}$ & $(a b)_{32}$ & $(a b)_{33}$ \\
\hline
\end{tabular}

Teknik pengambilan sampel yang digunakan pada penelitian ini adalah stratified cluster random sampling. Sehingga terpilih sekolah yang dijadikan tempat penelitian yaitu SMPN 3 Tanjungpandan kategori tinggi, SMPN 3 Sijuk kategori sedang dan SMPN 1 Badau kategori rendah. Penelitian ini merupakan penelitian ekperimental semu dengan populasi siswa kelas VII SMP di Kabupaten Belitung tahun pelajaran 2014/2015. Diperoleh sampel berjumlah 285 siswa dengan rincian 95 siswa di kelas eksperimen 1, 96 siswa di kelas eksperimen 2, dan 94 siswa di kelas kontrol. Teknik pengumpulan data menggunakan metode dokumentasi untuk melihat kemampuan awal, metode tes untuk mengukur prestasi belajar matematika dan metode angket untuk pengkategorian sikap siswa terhadap matematika.

Pada data kemampuan awal dilakukan uji normalitas dengan metode Lilliefors, uji homogenitas variansi dengan metode Bartlett dan uji keseimbangan menggunakan uji anava satu jalan. Uji hipotesis menggunakan anava dua jalan dan uji lanjut pasca anava menggunakan teknik Scheffe'.

\section{HASIL PENELITIAN DAN PEMBAHASAN}

Setelah dilakukan uji keseimbangan untuk mengetahui kemampuan awal masingmasing kelompok adalah sama. Selanjutnya dilakukan uji hipotesis. Berikut hasil rangkuman komputasi analisis variansi dua jalan dengan sel tak sama disajikan dalam Tabel 3 .

Tabel 3. Hasil Rangkuman Komputasi Analisis Variansi

\begin{tabular}{lcccccc}
\hline \multicolumn{1}{c}{ Sumber } & $\mathrm{JK}$ & $\mathrm{dk}$ & $\mathrm{RK}$ & $F_{\text {obs }}$ & $F_{\text {tab }}$ & Kep. uji \\
\hline Model pembelajaran $(a)$ & 3781,63 & 2 & 1890,81 & 15,95 & 3 & $H_{0 a}$ ditolak \\
\hline Sikap $(b)$ & 4441,67 & 2 & 2220,83 & 18,74 & 3 & $H_{0 b}$ ditolak \\
\hline Interaksi $(a b)$ & 2445,81 & 4 & 611,45 & 5,16 & 2,37 & $H_{0 a b}$ ditolak \\
\hline Galat & 32709,44 & 276 & 118,51 & & & \\
\hline Total & 43378,546 & 284 & & & & \\
\hline
\end{tabular}

Berdasarkan Tabel 3 dapat disimpulkan bahwa: (a) model pembelajaran berpengaruh terhadap prestasi belajar matematika siswa, (b) sikap siswa berpengaruh terhadap prestasi belajar matematika siswa, (c) ada interaksi antara model pembelajaran dan sikap siswa. Karena $H_{0 \mathrm{~A}}$ dan $H_{0 \mathrm{~B}}$ ditolak maka perlu dilakukan uji komparasi ganda antar baris dan antar kolom untuk mengetahui adanya perbedaan rerata yang signifikan 
antara prestasi belajar matematika. Sebelum melakukan komparasi ganda, dicari terlebih dahulu rerata marginal dan rerata masing-masing sel. Rangkuman hasil perhitungan terdapat pada Tabel 4 .

Tabel 4. Rangkuman Rerata Sel dan Rerata Marginal

\begin{tabular}{lcccc}
\hline \multirow{2}{*}{$\begin{array}{c}\text { Model } \\
\text { Pembelajaran }\end{array}$} & \multicolumn{3}{c}{ Sikap } & $\begin{array}{c}\text { Rerata } \\
\text { Marginal }\end{array}$ \\
\cline { 2 - 4 } PBL $\left(a_{1}\right)$ & Tinggi $\left(b_{1}\right)$ & Sedang $\left(b_{2}\right)$ & Rendah $\left(b_{3}\right)$ & 74,14 \\
\hline MMP $\left(a_{2}\right)$ & 82,32 & 76,78 & 63,64 & 71,53 \\
\hline Langsung $\left(a_{3}\right)$ & 75,44 & 70,60 & 67,45 & 65,46 \\
\hline Rerata Marginal & 66,48 & 65,52 & 64,27 & \\
\hline
\end{tabular}

Dari hasil perhitungan anava diperoleh keputusan bahwa $H_{0 A}$ ditolak, maka perlu dilakukan uji komparasi ganda antar baris.

Tabel 5. Rangkuman Uji Komparasi Ganda Prestasi Belajar Matematika antar Model Pembelajaran

\begin{tabular}{llccc}
\hline Komparasi Model Pembelajaran & $H_{0}$ & $F_{\text {obs }}$ & $F_{\text {tabel }}$ & Keputusan \\
\hline PBL-MMP & $\mu_{1}=\mu_{2}$ & 2,75 & 2,37 & $H_{0}$ Ditolak \\
\hline PBL-Langsung & $\mu_{1 .}=\mu_{3 .}$ & 30,06 & 2,37 & $H_{0}$ Ditolak \\
\hline MMP-Langsung & $\mu_{2 .}=\mu_{3}$. & 14,77 & 2,37 & $H_{0}$ Ditolak \\
\hline
\end{tabular}

Berdasarkan Tabel 4 dan Tabel 5, dapat disimpulkan bahwa model pembelajaran PBL menghasilkan prestasi lebih baik daripada model pembelajaran MMP, model pembelajaran PBL menghasilkan prestasi belajar matematika lebih baik daripada model pembelajaran langsung, dan model pembelajaran MMP menghasilkan prestasi belajar matematika lebih baik daripada model pembelajaran langsung. Hal tersebut didukung pula oleh Khan (2007) dalam penelitiannya menyatakan bahwa

"Cooperative learning in different cultures is a more effective mode of instruction for mathematics as compared to traditional method of teaching. Therefore, cooperative learning should be used to improve the academic achievements of students in mathematics. Moreover, mathematics teachers should be provided training in cooperative learning.

Model pembelajaran kooperatif lebih efektif daripada pembelajaran tradisional, pembelajaran kooperatif dapat meningkatkan kemampuan dalam hal aktivitas membaca dan menulis, sehingga membawa siswa dalam situasi dan interaksi bermakna untuk meningkatkan prestasi akademik.

Berdasarkan perhitungan uji anava $H_{0 B}$ ditolak, maka perlu dilakukan uji komparasi ganda antar kolom.

Tabel 6. Rangkuman Uji Komparasi Ganda Prestasi Belajar Matematika Antar Sikap Siswa Terhadap Matematika

\begin{tabular}{ccccc}
\hline Komparasi Sikap Siswa & $H_{0}$ & $F_{\text {obs }}$ & $F_{\text {tabel }}$ & Keputusan \\
\hline Tinggi-Sedang & $\mu_{.1}=\mu_{.2}$ & 6,24 & 2,37 & $H_{0}$ Ditolak \\
\hline Tinggi-Rendah & $\mu_{.1}=\mu_{.3}$ & 39,09 & 2,37 & $H_{0}$ Ditolak \\
\hline Sedang-Rendah & $\mu_{.2}=\mu_{.3}$ & 13,42 & 2,37 & $H_{0}$ Ditolak \\
\hline
\end{tabular}


Berdasarkan Tabel 4 dan Tabel 6, dapat disimpulkan bahwa siswa dengan sikap tinggi terhadap matematika mempunyai prestasi belajar matematika lebih baik daripada siswa dengan sikap sedang, siswa dengan sikap tinggi terhadap matematika mempunyai prestasi belajar matematika lebih baik daripada siswa dengan sikap rendah, siswa dengan sikap sedang terhadap matematika mempunyai prestasi belajar matematika lebih baik daripada siswa yang mempunyai sikap rendah. Martino (2009) menyatakan "Positive attitude towards mathematics is thought to play an important role in causing student to learn mathematics". Sikap positif terhadap matematika memainkan peran yang penting bagi siswa dalam mempelajari matematika. Sikap tinggi terhadap matematika tentunya sangat menguntungkan dan mengakibatkan prestasi yang baik dalam mata pelajaran.

Berdasarkan hasil perhitungan anava $H_{0 A B}$ ditolak, maka terdapat interaksi. Selanjutnya dilakukan uji komparasi ganda antar sel pada baris yang sama. Hasilnya ditunjukkan pada Tabel 7.

\section{Tabel 7. Rangkuman Komparasi Ganda Antar Sel Pada Baris Yang Sama}

\begin{tabular}{cccc}
\hline$H_{0}$ & $F_{\text {obs }}$ & $D K$ & Keputusan \\
\hline$\mu_{11}=\mu_{12}$ & 7,064 & $\{F \mid F>15,52\}$ & $H_{0}$ tidak ditolak \\
\hline$\mu_{11}=\mu_{13}$ & 34,925 & $\{F \mid F>15,52\}$ & $H_{0}$ ditolak \\
\hline$\mu_{12}=\mu_{13}$ & 11,947 & $\{F \mid F>15,52\}$ & $H_{0}$ tidak ditolak \\
\hline$\mu_{21}=\mu_{22}$ & 4,599 & $\{F \mid F>15,52\}$ & $H_{0}$ tidak ditolak \\
\hline$\mu_{21}=\mu_{23}$ & 16,044 & $\{F \mid F>15,52\}$ & $H_{0}$ ditolak \\
\hline$\mu_{22}=\mu_{23}$ & 3,202 & $\{F \mid F>15,52\}$ & $H_{0}$ tidak ditolak \\
\hline$\mu_{31}=\mu_{32}$ & 1,923 & $\{F \mid F>15,52\}$ & $H_{0}$ tidak ditolak \\
\hline$\mu_{31}=\mu_{33}$ & 0,052 & $\{F \mid F>15,52\}$ & $H_{0}$ tidak ditolak \\
\hline$\mu_{32}=\mu_{33}$ & 1,278 & $\{F \mid F>15,52\}$ & $H_{0}$ tidak ditolak \\
\hline
\end{tabular}

Berdasarkan Tabel 7 dapat disimpulkan bahwa pada pembelajaran dengan model PBL, siswa dengan sikap tinggi terhadap matematika mempunyai prestasi belajar matematika yang sama baiknya dengan sikap sedang terhadap matematika. Siswa dengan sikap tinggi terhadap matematika mempunyai prestasi belajar matematika lebih baik dengan sikap rendah terhadap matematika. Siswa dengan sikap sedang terhadap matematika mempunyai prestasi belajar matematika sama baiknya dengan sikap rendah terhadap matematika.

Pada model pembelajaran MMP, siswa dengan sikap tinggi terhadap matematika mempunyai prestasi belajar matematika yang sama baiknya dengan sikap sedang terhadap matematika. Siswa dengan sikap tinggi terhadap matematika mempunyai prestasi belajar matematika lebih baik daripada sikap rendah terhadap matematika. Siswa dengan sikap sedang terhadap matematika mempunyai prestasi belajar matematika yang sama baiknya dengan sikap rendah terhadap matematika. Sedangkan pada pembelajaran dengan model langsung, pada setiap tingkatan sikap siswa memberikan efek yang sama. Siswa dengan 
sikap tinggi, sedang, rendah terhadap matematika mempunyai prestasi belajar matematika yang sama baiknya.

Model pembelajaran juga ikut mempengaruhi prestasi belajar matematika siswa. Penggunaan model pembelajaran yang berbeda pada setiap kegiatan belajar mengajar dapat memberikan tingkat keefektifan yang berbeda sesuai dengan potensi kemampuan yang dimiliki oleh masing-masing siswa. Pada siswa dengan sikap tinggi, sedang dan rendah terhadap matematika jika menggunakan model pembelajaran yang tepat maka prestasi belajar matematika akan maksimal. Hal ini didukung oleh penelitian yang dilakukan Taylor (2004) dalam Norila binti Md Salleh (2014: 968) bahwa untuk mengubah sikap siswa terhadap matematika hendaknya guru lebih kreatif dalam pembelajaran misalnya dengan penggunaan model pembelajaran.

Berdasarkan hasil perhitungan analisis variansi dua jalan dengan sel tak sama diperoleh bahwa $H_{0 A B}$ ditolak. Ini berarti, antara model pembelajaran dan sikap siswa terdapat interaksi terhadap prestasi belajar. Jika $H_{0 A B}$ ditolak maka dilakukan uji komparasi ganda antar sel pada baris yang sama dengan uji Shceffe'. Hasil ujinya ditunjukkan pada Tabel 8.

Tabel 8 Rangkuman Komparasi Ganda Antar Sel Pada Kolom Yang Sama

\begin{tabular}{cccc}
\hline$H_{0}$ & $F_{\text {obs }}$ & $D K$ & Keputusan \\
\hline$\mu_{11}=\mu_{21}$ & 4,000 & $\{F \mid F>15,52\}$ & $H_{0}$ tidak ditolak \\
\hline$\mu_{11}=\mu_{31}$ & 48,618 & $\{F \mid F>15,52\}$ & Ditolak \\
\hline$\mu_{21}=\mu_{31}$ & 22,504 & $\{F \mid F>15,52\}$ & Ditolak \\
\hline$\mu_{12}=\mu_{22}$ & 3,190 & $\{F \mid F>15,52\}$ & $H_{0}$ tidak ditolak \\
\hline$\mu_{12}=\mu_{32}$ & 9,038 & $\{F \mid F>15,52\}$ & $H_{0}$ tidak ditolak \\
\hline$\mu_{22}=\mu_{32}$ & 1,212 & $\{F \mid F>15,52\}$ & $H_{0}$ tidak ditolak \\
\hline$\mu_{13}=\mu_{23}$ & 0,126 & $\{F \mid F>15,52\}$ & $H_{0}$ tidak ditolak \\
\hline$\mu_{13}=\mu_{33}$ & 0,652 & $\{F \mid F>15,52\}$ & $H_{0}$ tidak ditolak \\
\hline$\mu_{23}=\mu_{33}$ & 0,632 & $\{F \mid F>15,52\}$ & $H_{0}$ tidak ditolak \\
\hline
\end{tabular}

Berdasarkan Tabel 8 dapat disimpulkan bahwa pembelajaran pada siswa dengan sikap tinggi terhadap matematika, model PBL menghasilkan prestasi belajar matematika yang sama baiknya dengan model pembelajaran MMP. Model PBL menghasilkan prestasi belajar matematika lebik baik daripada model pembelajaran langsung. Siswa yang dikenai model pembelajaran MMP menghasilkan prestasi belajar matematika yang lebih baik daripada model pembelajaran langsung.

Pada siswa dengan sikap sedang terhadap matematika, model PBL menghasilkan prestasi belajar matematika yang sama baiknya dengan model pembelajaran MMP. Model pembelajaran PBL menghasilkan prestasi belajar matematika yang sama baiknya model pembelajaran langsung. Model pembelajaran MMP menghasilkan prestasi belajar matematika yang sama baiknya dengan model pembelajaran langsung. 
Pada siswa dengan sikap rendah terhadap matematika, model PBL menghasilkan prestasi belajar matematika yang sama baiknya dengan model pembelajaran MMP. model PBL menghasilkan prestasi belajar matematika yang sama baiknya dengan model pembelajaran langsung. Model pembelajaran MMP menghasilkan prestasi belajar matematika yang sama baiknya dengan model pembelajaran langsung.

Sikap siswa terhadap matematika merupakan faktor internal yang sangat mempengaruhi prestasi belajar matematika siswa. Hal ini didukung dengan pendapat Akinsola and Olowojaiye (2008) yang menyatakan bahwa sikap siswa terhadap mata pelajaran menentukan keberhasilan mereka dalam mata pelajaran itu. Akibatnya, sikap yang menguntungkan mengakibatkan prestasi yang baik dalam mata pelajaran

\section{SIMPULAN DAN SARAN}

Berdasarkan kajian teori dan didukung adanya analisis serta mengacu pada rumusan masalah yang telah diuraikan, dapat disimpulkan bahwa: (1) model PBL menghasilkan prestasi belajar matematika lebih baik daripada model pembelajaran MMP maupun model pembelajaran langsung. Model pembelajaran MMP menghasilkan prestasi belajar matematika lebih baik daripada model pembelajaran langsung. (2) siswa dengan sikap tinggi terhadap matematika mempunyai prestasi belajar matematika lebih baik daripada siswa dengan sikap sedang maupun sikap rendah terhadap matematika. Siswa dengan sikap sedang terhadap matematika mempunyai prestasi belajar matematika lebih baik daripada siswa dengan sikap rendah terhadap matematika.

Kesimpulan setiap model pembelajaran untuk semua kategori sikap: (3a) Pada model pembelajaran PBL, siswa dengan sikap tinggi terhadap matematika mempunyai prestasi belajar matematika yang sama baiknya dengan sikap sedang terhadap matematika. Siswa dengan sikap tinggi terhadap matematika mempunyai prestasi belajar belajar matematika yang lebih baik daripada sikap rendah terhadap matematika. Siswa dengan sikap sedang terhadap matematika mempunyai prestasi belajar matematika yang sama baiknya dengan sikap rendah terhadap matematika. (3b) Pada model pembelajaran MMP, siswa dengan sikap tinggi terhadap matematika mempunyai prestasi belajar matematika yang lebih baik daripada sikap rendah terhadap matematika. Untuk sikap sedang dan rendah terhadap matematika menghasilkan prestasi belajar matematika yang sama baiknya. (3c) Pada model pembelajaran langsung siswa, untuk sikap tinggi, sedang dan rendah terhadap matematika memiliki prestasi belajar matematika yang sama baiknya.

Kesimpulan setiap kategori sikap pada model pembelajaran: (4a) Pada sikap tinggi terhadap matematika, model pembelajaran PBL dan model pembelajaran MMP 
menghasilkan prestasi belajar matematika yang sama baiknya. Model PBL meghasilkan prestasi belajar matematika yang lebih baik daripada model pembelajaran langsung. Model pembelajaran MMP lebih baik daripada model pembelajaran langsung. (4b) Pada sikap sedang terhadap matematika, siswa yang dikenai model PBL, model pembelajaran MMP dan model pembelajaran langsung mempunyai prestasi belajar matematika yang sama baiknya. (4c) Pada sikap rendah terhadap matematika, siswa yang dikenai model pembelajaran yaitu PBL, MMP dan langsung mempunyai prestasi belajar matematika yang sama baiknya.

Adapun saran dari hasil penelitian ini adalah dengan memilih model pembelajaran kooperatif yang sesuai untuk diterapkan dalam proses pembelajaran, misalnya model pembelajaran PBL dan MMP seperti dalam penelitian ini. Model pembelajaran PBL dan MMP memberikan prestasi belajar belajar matematika yang lebih baik dibandingkan model pembelajaran langsung. Selain itu siswa diharapkan lebih berani dalam mengungkapkan ide-ide matematika agar dapat mengkonstruksi dan memecahkan masalah matematika selama pembelajaran berlangsung. Sehingga dengan menggunakan model pembelajaran tersebut prestasi siswa dengan kategori sikap sedang dan rendah terhadap matematika bisa menyamai prestasi siswa dengan sikap tinggi terhadap matematika. Guru hendaknya memperhatikan siswa dengan kategori sikap yang dimiliki siswa, sehingga guru dapat menyikapi perbedaan tersebut dalam proses pembelajaran.

\section{DAFTAR PUSTAKA}

Akinsola, MK, and Olowojaiye, FB. 2008. Teacher Instructional Methods and Student Attitudes Towards Mathematics. International Electronic Journal of Mathematics Education Vol 3, No 1, 60-73.

Awofala, AOA. 2014. Examining Personalisation of Instruction, Attitudes Toward and Achievement in Mathematics Word Problems among Nigerian Senior Secondary School Students. International Journal of Education in Mathematics, Science and Technology, Vol 2, Number 4, 273-288.

Ball, CT and Pelco, LT. 2006. Teaching Research Methods to Undergraduate Psychology Students Using an Active Cooperative Learning Approach. Volume 17, Number 2, 147-154 ISSN 1812-9129.

Bilgin, I, Senocak, E, and Sözbilir, M. 2009. The Effects of Problem-Based Learning Instruction on University Students Performance of Conceptual and Quantitative Problems in Gas Concepts. Eurasia Journal of Mathematics, Science \& Technology Education, Vol.5, No. 2, 153-164.

Farooq, MS, and Shah, SZU. 2008. Students' Attitude Towards Mathematics. Pakistan Economic and Social Review. Vol. 46, No. 1 (Summer 2008), pp. 75-83. 
Khan, AB. 2007. Effects of Cooperative Learning on Academic Achievement and Retention of Secondary Grader Mathematics Students. Journal of Educational Research Vol.10, No. 1, 1-100.

Kiran, A, Qaisara, P, Sidra, K, Mehwish, R, and Amna, K. S. 2012. A Study of Student's Attitudes towards Cooperative Learning. International Journal of Humanities and Social Science. Vol 2, No. 11, 141-147.

Kupczynski, L, Marie, AM, Jaya, G, and Vanessa, M. 2012. Cooperative Learning In Distance Learning: A Mixed Methods Study. International Journal of Instruction. Vol 5, No. 2, 81-90.

Mahanta, D. 2012. Achievement in Mathematics: Effect of Gender and Positive/Negative Attitude of Students: International Journal of Theoretical \& Applied Sciences. Vol. 4, No. 2 : 157-163.

Martino. 2009. The Role of Affect In The Research on Affect The Case of Attitude. Pisa, Italy: European Research In Mathematics Education III.

Norila binti Md Salleh, and Ikhsan bin Othman. 2014. The Effects of Integrating Emotional Intelligence on Students Attitudes Toward Mathematics: International Journal of Asian Social Science, Vol. 4, No. 9, pp. 966-976.

Zakaria, E, and Iksan, Z. 2007. Promoting Cooperative Learning in Science and Mathematics Education: A Malaysian Perspective. Universiti Kebangsaan, Selangor, Malaysia: Eurasia Journal of Mathematics, Science \& Technology Education, 3(1), 35-39. ISSN: 1305-8223. 